\title{
The effect of industrial park development on people's lives
}

\section{Thi Yen Le ${ }^{a^{*}}$, Van Hung Pham ${ }^{b}$, Thanh Thuy Cuc ${ }^{c}$ Minh Hoa Pham ${ }^{d}$ and Quyet Thang Dao}

\author{
${ }^{a}$ Thai Nguyen University of economics and business administration, Vietnam \\ ${ }^{b}$ National Economics University, Vietnam \\ ${ }^{c}$ Hanoi Architectural University, Vietnam \\ ${ }^{d}$ Ministry of Finance, Vietnam \\ ${ }^{e}$ Quy Nhon University, Vietnam

CHRONICLE ABSTRACT

Article history:
Received: November 17, 2019
Received in revised format: No-
vember 302019
Accepted: December 16, 2019
Available online:
December 16, 2019
Keywords:
Industrial parks
Livelihoods
Impacts of industrial park devel-
opment
Sustainability
Vietnam

\begin{abstract}
This paper examines the effect of industrial park development on people's livelihoods through different impacting channels; including employment, production means and infrastructure. The result of the research shows that industrial park development had a positive influence on people's livelihoods through additional employment, non-farm investments, access to policies, household labor, etc. However, industrial park development also causes negative impacts on people's livelihoods causing unemployment. Data for research is collected from households including land acquisition and no land acquisition living around industrial parks. Research findings can be considered as a basis to help develop the positive influence and restrict the negative influence of industrial park development on people's livelihoods in Vietnam.
\end{abstract}

\section{Introduction}

The model of industrial parks has been built and developed in countries as an effective capital mobilization channel to achieve socio-economic goals such as economic development of localities where industrial parks are built and put into operation, animate the development of service industries, supporting industries, job creation, boost income for local people and surrounding areas (Benayas et al., 2007; Bryceson, 1996; Thuận et al., 2018). The industrial park was built to concentrate the most favorable conditions for domestic and foreign investors, and contribute to increasing the attractiveness and competitiveness of the nation's investment environment. By the end of 2018, Vietnam built 326 industrial parks out of a total of 463 planned industrial parks, the total natural land area of these industrial parks was approximately 93,000 hectares, where 56,000 hectares of industrial land was leased accounting for about $66 \%$ of the total natural land area. Industrial parks throughout the country have attracted about 7500 domestic investment projects with a total registered capital of about 970 trillion dong and about 8000 projects of foreign investment with a total registered capital of about 145 billion USD. The occupancy rate of industrial parkland area is about 73\% (Department of Economic Zone Management, Ministry of Planning and Investment, 2019). These industrial parks established and developed have contributed to economic restructuring, create jobs for a large part of the labor force, developing local supporting industries and services. Specifically, in 2017, the size of the labor force working in industrial parks of the central key economic region was approximately 151,043 workers, which focuses on the provinces of Binh Dinh, Da Nang, Thua Thien Hue, Quang Nam and Quang Ngai. However, in addition to the positive impacts

* Corresponding author. Tel.: +84988054924

E-mail address: lethiyenktdt@gmail.com (T.Y. Le) 
from industrial park development that bring about the economy and the people, there are also negative impacts: a large amount of agricultural and residential land of people was recovered when the industrial park was built and developed. According to data from the Ministry of Agriculture and Rural Development, an average of 73 thousand hectares of agricultural land is annually acquired, affected the lives of about 2.5 million people and for every 1 ha of land acquired, 10 people lost their jobs. This has greatly influenced and changed the livelihood strategies of people living around industrial parks.

This research was conducted to analyze the positive and negative effects of industrial park development on people's livelihoods. For people living around industrial parks, this study has access to both groups of households whose agricultural lands were recovered and groups of people living around industrial parks (without agricultural land acquisition). Therefore, the author's team conducted this research to ensure the creation and necessary for research.

\section{Research overview}

In the context of the phenomenon of increasing agricultural land acquisition due to urbanization and industrialization in many suburbs of major cities, Vietnamese researchers have been trying to find out how the loss of agricultural land affected the income of rural households, in these studies, quantitative or descriptive statistical methods were used to analyze data. Secondary data were collected from various publications in Vietnam, Nguyen et al. (2006) point out that in previous decades, Vietnam has experienced rapid urbanization and industrialization in suburban areas, as a result of this process, a large number of rural households have lost their agricultural lands to the development of industrial parks and urban areas, and many of them have fallen into poverty. However, some case studies in suburban areas of Ho Chi Minh City and Hanoi show the mixed effect of agricultural land acquisition on local people's income. When studying the case in a village on the outskirts of Hanoi, where two-thirds of agricultural land was lost due to urbanization between 1998 and 2007, Van Suu (2009) found that many households have benefited from their proximity to universities and central cities. Income from rental accommodation for students and migrant workers emerged as the most important source of income for the majority of households. However, some other households face insecure lives because they do not have rooms for rent and many landless farmers have become unemployed, especially the elderly and the poorly educated farmers. By using quantitative methods to access household livelihoods to investigate the impact of these factors on income and household spending in peri-urban areas of Hanoi, Tran Quang Tuyen and Tuyen and Van Huong (2014) showed some evidence that agricultural land had an influence on household income, when losing agricultural land had a negative influence on household farm income, but it had a positive effect on households as employment in non-agricultural sectors increases. At the same time, in this study, the author also pointed out that professional qualifications and skills also affect household income. The study also shows that education and business facilitation are important factors that can encourage households to pursue non-farm activities to generate additional income for households. Besides, parents' support to teach their children can be a way to get paid jobs for the next generation. Finally, the authors also pointed out that improving the infrastructure of localities, expanding product consumption markets are also positive measures to expand non-agricultural employment opportunities for people. This is also a relatively effective measure for increasing profits for people.

There are several studies on the effects of losing land in the process of urbanization and the process of building indsutrial parts. This study has determined the situation of household earnings after land loss, people's employment standing, and analysis of factors affecting the livelihood of people losing land. The factors selected for analysis have significant similarities between these studies: education, number of workers, gender of household head, area of agricultural land, participate in social organizations of household members, access to credit, etc. With the study of author Le Du Phong (2007), the results extracted from the topic statistically recalculated all localities in Vietnam from changes in income, changes in jobs, ways of using compensation money for land lost due to industrial park construction, or urbanization. In the study of Tuyen (2013), the author quantified the relationship between the factors affecting people's income and collected data from 477 households losing land in suburban Hanoi. In this survey, factors affecting people's income had similarities with previous studies when using factors such as area, the number of household members, the gender of head of household, age of head of household, average age of members is labour force in the family and average level of education of household members.

Several studies have been carried out to assess the impact of industrial parks on the national socio-economic development such as Damborský et al. (2013), Jansen et al. (2006), Nelson et al., (2005, 2010), Blomström and Kokko (1998), Blomström and Sjöholm (1999), Melnyk et al. (2014), Popescu and Avramescu (2008). These researches tried to improve the attraction of foreign direct investment (FDI) in industrial parks in particular and in the nation in general. The research method used in the studies is a descriptive statistical method with data collected by questionnaires with enterprises running in national industrial parks. Based on the handled data, the author calculated the effect of industrial parks on the local socio-economic development through the amount of tax collected by the government, the number of jobs created, etc. These studies are just limited for describing the results collected from interviews with enterprises in the industrial park and have not yet quantified the relationship between the resources that the locality and the government get with the activities of enterprises. Besides, industrial parks are built not only to attract investment capital from foreign corporations, a large proportion of enterprises operating in industrial parks are domestic enterprises, the benefits that these companies generate are similarly contributed to foreign enterprises. Therefore, a comprehensive study of both the influence of domestic and foreign enterprises on local socio-economic 
development is necessary. Besides, a number of studies have been carried on the influence of industrialization on the livelihoods of people losing land. A study was conducted by Paul and Sarma (2013) to assess the level of people's satisfaction with infrastructure when industrial parks are built. The authors used the least square method in evaluating the impact of factors on the livelihood of people losing land. They reported that people had a good assessment of the infrastructure system after the industrial park was built and the ability to access roads, electricity and clean water with people was better. However, there was a difference in the results of this study that a better infrastructure system lowered people's income. Fig. 1 shows the summary of the impact channels of industrial parks development on people's livelihoods

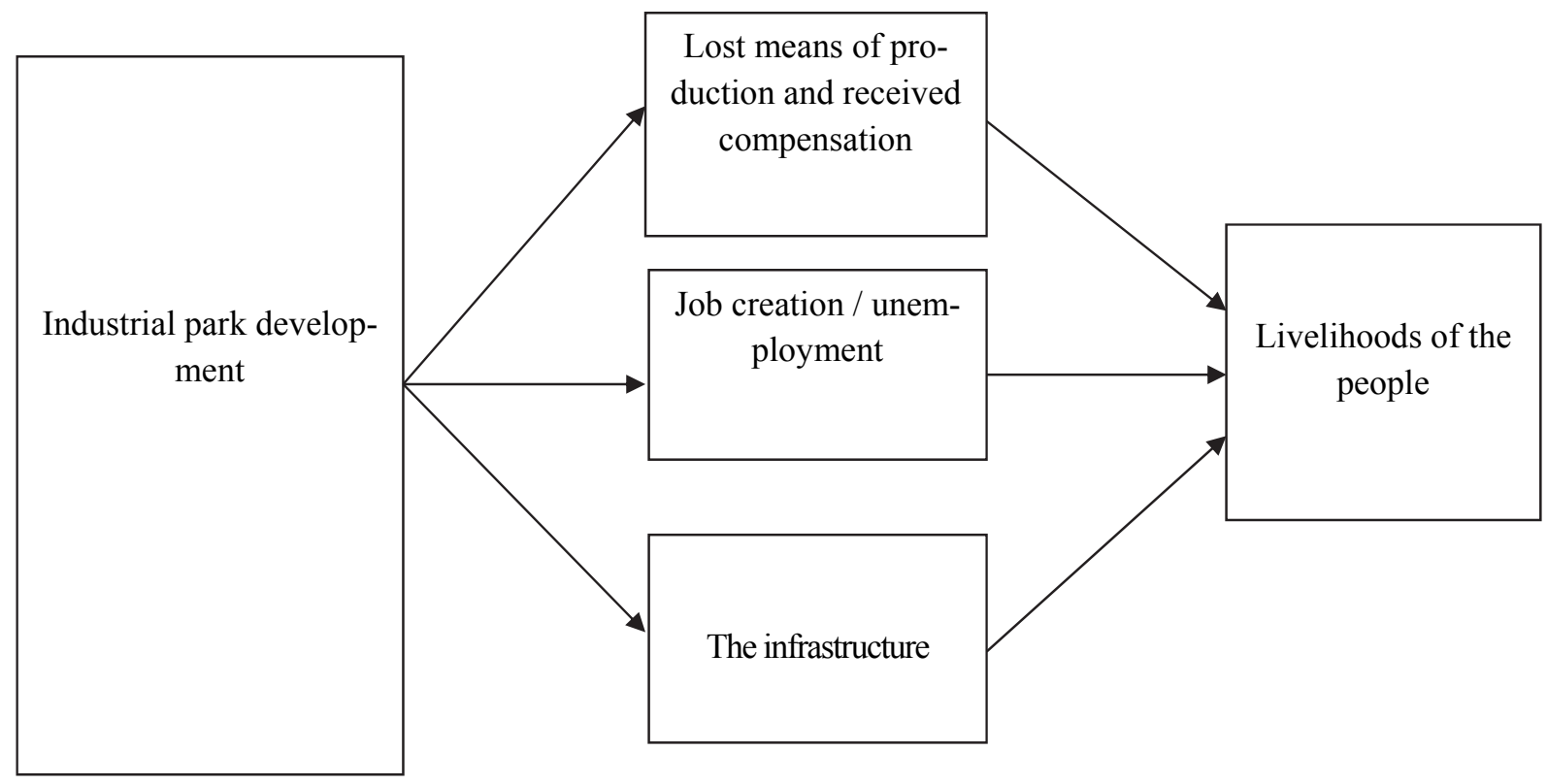

Fig. 1. Summary of the impact channels of industrial parks development on people's livelihoods Source: Building by authors

Industrial park development will also attract a large part of labors working in industrial parks, so creating jobs for people, however, will also cause unemployment for people who lose their means of production but do not meet the professional requirements as well as the skills necessary to work in industrial parks. Therefore, job creation or unemployment due to industrial park development also have positive and negative impacts on people's livelihoods (which can cause income changes for people). Development of industrial parks will also have an influence on infrastructure when industrial parks are established and developed and it will contribute to improve the local infrastructure as follows: infrastructure formed and upgraded: planning industrial parks challenges the structure of technical infrastructure systems such as electricity and water, communications, drainage systems, transportation systems and social infrastructure such as schools and hospitals. On the other hand, the industrial park is built to attract a large number of workers from other regions, hence promoting the process of reallocating the local population and facilitate urbanization. Building the industrial parks also led to the development of service infrastructure such as banks, post offices, supermarkets, trade centers, etc. so people can have access to these services in more convenient way. However, there will also be negative impacts on people's lives if the planning of industrial parks is not synchronized with the planning of infrastructure. While the infrastructure has not been built yet, the operation of industrial parks entails the operation of a large number of vehicles entering and leaving the industrial parks could lead to quicker and more severe deterioration of road systems.

\section{Research Methodology}

\subsection{Data collection methods}

Based on the 2006 General Statistics Office questionnaire (GSO, 2006), the designer has designed household questionnaires to collect quantitative data for research. Data in the questionnaire included household characteristics, resources, household livelihood assets and household income. The authors distributed 400 questionnaires and 230 survey questionnaires were collected corresponding to 230 families decided for interview, where 123 families were those who lost land to build industrial parks, including a groups of households lost all agricultural land, a group of households lost part of it, some households lost only a very small part of their total land area and 107 households did not lose land. Determining the sample size, in the process of studying socio-economic issues, it is very important to select a representative sample that is large enough. Factors that need to be considered to determine the exact sample size for a study include accuracy, quality of data, cost and 
time for data collection. Primary data was collected from early April to the end of October 2018 by using the questionnaire through direct interviews with the head of the household in the presence of other family members. The authors used direct survey method to collect information about households and used direct survey method in combination with collecting data related to income, the employment of households in the surveyed communes for this study. The descriptive statistical results of the observations are shown in Fig. 2

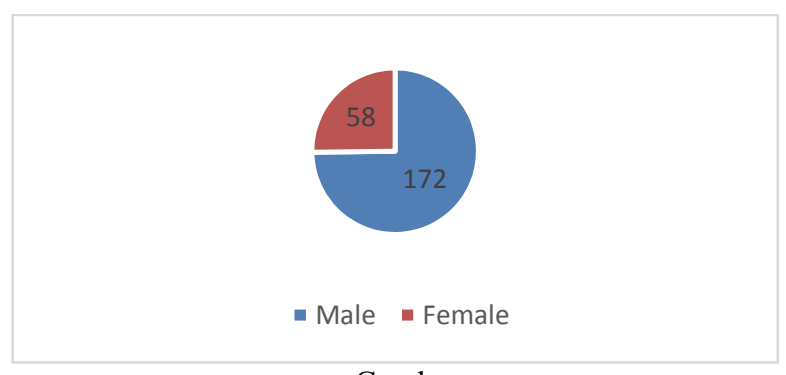

Gender

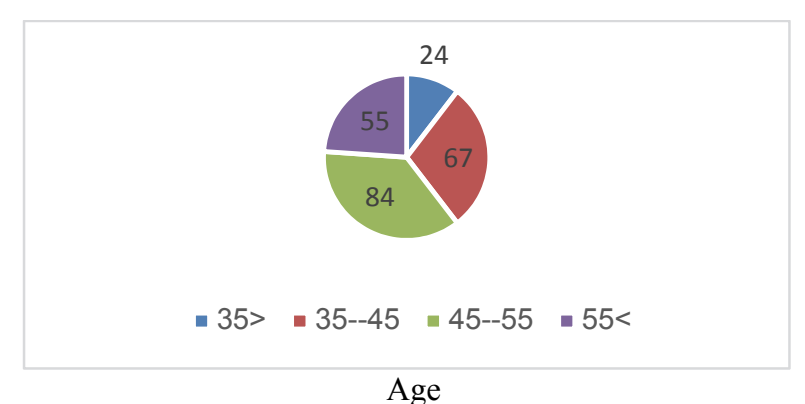

Age

Fig. 2. Descriptive statistics for observations

Besides, the research also used a focus group discussion method to collect data supporting the analysis of quantitative data. According to Van Thang (2014), group discussion is often applied when collecting data on emotions, opinions and opinions of a group of people related to research issues. The group discussion method was used by the authors to get the necessary data on people's views and opinions, including the group of households whose land was recovered and the group of households without land acquisition due to the development of industrial parks, on the impact of industrial park development on the people's livelihood, particularly two groups of households: households losing land and households without losing land. Specifically, the author selected and invited two groups for group discussion, each discussion group consisted of four representatives for four households, the representative of each household must ensure knowledge of the family's economic conditions as well as knowledge of the influence of industrial park development on the household's livelihood. Individuals participating in group discussions live in the same residential area and with socioeconomic conditions, may have different views on the impact of industrial park investment on people's livelihoods. Time for group discussion: On the morning of July 1 and the morning of July 2, 2018, locations: for a group of households whose land was not acquired, the authors invited the discussion group to come to Ms Nguyen Thi Trang's house, address: Ba Hang Town, Pho Yên District. With the group of households whose land was recovered, the authors invited the representative of the discussion group to visit Mr Nguyen Van Cuong's house, address: Diem Thuy commune, Phu Binh district to conduct group discussion.

To prepare for the group discussion, the authors prepared a group discussion guide and specified the array of information to exploit and learn to have an objective assessment of the households on the impact of investment in the development of industrial zones on people's livelihoods. Specifically, the authors planned to receive the opinions of the participants in the group discussion about their ideas on the following problem areas: How the development of industrial parks affects the family's income, employment, the family services, new family livelihood strategy, education, transportation, etc. of households. Family recommendations to further strengthen the livelihoods of households. Comments, share of group discussion were noted specifically, fully and saved in the data file. Results of group discussions will help for the analysis and collect a more multidimensional perspective, an effective support for the results of quantitative analysis of the author on the impact of industrial park development investment on people's livelihoods.

\subsection{Modeling method}

Using quantitative data collected, the research team used a quantitative model to analyze the impact of industrial park development on the livelihoods of people living around the industrial parks.

\section{The dependent variable}

+) The livelihood of households living around industrial parks: the author used the income scale of people living around industrial parks to measure this variable. Household income is the total income that a household earns in a year as a unit of income: Million $\mathrm{VND}$ / year. The income scale used was the one that represents the author's livelihood variables inherited from previous studies done relating to livelihoods, specifically, the author inherits the research of Tuyen (2013), Tuyen and Huong (2014) and Siegel (2005)

\section{The independent variables}

+) Land area lost due to industrial park development (S_dat_bi_mat): the area of land that households are acquired when constructing industrial parks. The unit of calculation is $\mathbf{m}^{2}$. According to research by Van Suu (2009) when a family loses land by building an industrial park or for other purposes, a part of people will have an increase in income when they have 
enough resources as well as take advantage of the process of industrialization and urbanization. However, a part of other people will face a troubled life because when they lose land they will be unemployed.

+) Accessibility of preferential policies of households (Tiep_can_CS): this is a dummy variable used by the authors to consider the accessibility of policies of households. The value of the variable will return a value of 1 if the household has entrance to incentives and a value of 0 if unavailable.

+) Non-agricultural investment (DT_Phi_NN): Actual investment of households for non-agricultural activities such as building houses, investing in services, etc. Unit of calculation is VND million / year.

+) Transportation system after industrial park (Giao_Thong): As the evaluation variable of households on the transport system after industrial parks are built, it returns 1 if the answer is that the communication system is very bad, returns 2 if the answer is terrible, returns 3 if the answer is a normal transportation system, returns 4 if the transit is good and 5 if the traffic is excellent. In the study of Paul and Sarma (2013), the authors pointed out that, better infrastructure system reduces people's income.

+) Number of jobs available when the industrial park is built (SL_Viec_lam_KCN): it is the number of jobs calculated for each additional household when industrial parks are built. The unit of calculation is the employee. In the study of Phong (2007) and Tran Quang Tuyen (2013), the number of jobs increased contributed to people's income.

+) Number of workers in industrial parks (SL_LD_KCN): is the number of employees working directly in the industrial park.

+) Number of unemployed laborers upon the construction of industrial park (SL_that_ngiep_KCN): the number of employees in each household who was unemployed when the industrial park was built. Calculation unit: Workers. According to Van Suu (2009) and Lê Du Phong (2007), unemployment is the cause of households' poverty. The relationship between unemployed labor and household income is the opposite.

\section{The control variables}

Number of workers in the household (So_Luong_Lao_Dong_Ho): Reflecting the actual number of employees in the household who can participate in production and business activities to generate household income.

Therefore, the research model has the form:

$\mathrm{Y}_{\mathrm{i}}=\mathrm{a}+\mathrm{b}_{1}(\mathrm{~S}$ _dat_bi_mat $)+\mathrm{b}_{2}$ (Tiep_can_CS $)+\mathrm{b}_{3}\left(\mathrm{DT} \_\right.$Phi_NN $)+\mathrm{b}_{4}(\mathrm{Giao}$ thong $)+\mathrm{b}_{5}\left(\mathrm{SL} \_\mathrm{Viec} \_\right.$Lam_KCN $)+\mathrm{b}_{6}$ $\left(\mathrm{SL} \_\mathrm{LD} \_\mathrm{KCN}\right)+\mathrm{b}_{7}\left(\mathrm{SL}_{-}\right.$that_nghiep_KCN$)+\mathrm{b}_{8}($ So_luong_lao_dong_ho $)+\mathrm{U}_{\mathrm{i}}$

\section{Research findings}

By interviewing 230 households who live around industrial parks, affected by industrial parks, the authors examined both positive and negative impacts of industrial park development on people's livelihoods, the scale chosen by the author is people's income, with specific results as follows:

\section{Table 1}

Descriptive Statistics

\begin{tabular}{lcc}
\hline & Mean & Std. Deviation \\
\hline Y & 123.860 & 93.0216 \\
S_dat_bi_mat & 676.96 & 1067.066 \\
Tiep_can_CS & .29 & .455 \\
DT_Phi_NN & 38.238 & 91.5241 \\
Giao_thong & 2.72 & .911 \\
SL_Viec_lam_KCN & 1.20 & .996 \\
SL_LD_KCN & 1.08 & 230 \\
SL_that_nghiep_KCN & .81 & 230 \\
So_luong_lao_dong_ho & 2.66 & .923 \\
\hline
\end{tabular}

Source: Processing results from the survey data

The survey results show that the average income of the selected households is 123.86 million VND/year, where, when considering each audience group, there is a relatively clear difference in the income of the non-losing households and the loss of land due to the development of industrial parks. It seems that the average income of households losing land is higher than the average income of non-losing households according to the survey results showing: The average income of the group of households losing land as a result of the survey is VND 168.745 million/year comparing to 72.263 million dongs/year, it is the 
income of non-losing households. This result is similar to the view of author Van Suu (2009) when the authors think that households losing land would receive a relatively large amount of compensation. In fact if these households can adapt and make good use of this money, they will open job opportunities from non-agricultural activities such as services, motels for workers and it will become a new livelihood strategy for the people.

Table 2

Descriptive statistics results in income by household group

\begin{tabular}{lccc}
\hline & Mean & Std. Deviation & $\mathrm{N}$ \\
\hline Income of households losing land & 168.745 & 104.9947 & 123 \\
Income of households do not lose land & 72.263 & 31.3172 & 107 \\
\hline
\end{tabular}

Source: Processing results from the survey data

The research findings also show that the investment of households in non-agricultural activities was relatively high for each year, the average value of each year was VND 38.238 million/year. This money was invested by households in some investment items such as building houses for rent to workers, investing in service activities. This is also one of the reasonable trends in the context of the country's industrialization and modernization. The number of jobs increased when the industrial parks were building an average 1.2 worker/household and the number of jobs increased when constructing industrial parks of households lost land higher than households without losing land (1.49 extra jobs/household lost land compared to 0.88 extra jobs / non-losing household), this phenomenon is partly due to the case that households who lose land were given priority in recruiting to production and business establishments in industrial parks. Transportation system according to the assessment of people living around the industrial parks after the industrial parks reached an average level, with an average people's score of about 2.72 points. This is not a good number, but it also partly satisfies people's satisfaction with this item after the construction of industrial parks. It contributes to helping people be more convenient in the process of carrying out their livelihood activities, opening new directions and livelihood strategies for people. Besides, other results show that, when investment and development activities of industrial parks are carried out, in addition to creating jobs for people living around industrial parks, there are also negative impacts, when a part of the people have not been able to adapt or adapt to new environmental changes, have not found a new livelihood strategy to stabilize their lives, a part of the members of these households became unemployed, the results showed that the number of unemployed laborers after the industrial parks were built was relatively large: 1.26 workers/households without land loss were surveyed and 0.42 workers/each household lost land surveyed, collecting data, on average, the total number of unemployed population in the survey was about 0.81 workers/household

\section{Accreditation of conformity and some defects of the model}

With the proposed research model, the authors conducted the test on the suitability of the regression function form and some shortcomings of the model and Table 3 shows the summary of the results.

Table 3

Summary parameters of the model

\begin{tabular}{|c|c|c|c|c|c|c|c|c|c|c|}
\hline \multirow[b]{2}{*}{ Model } & \multirow[b]{2}{*}{$\mathrm{R}$} & \multirow{2}{*}{$\begin{array}{c}\mathrm{R} \\
\text { Square }\end{array}$} & \multirow{2}{*}{$\begin{array}{l}\text { Adjusted } \\
\text { R Square }\end{array}$} & \multirow{2}{*}{$\begin{array}{l}\text { Std. Error } \\
\text { of the Es- } \\
\text { timate }\end{array}$} & \multicolumn{5}{|c|}{ Change Statistics } & \multirow{2}{*}{$\begin{array}{l}\text { Durbin- } \\
\text { Watson }\end{array}$} \\
\hline & & & & & $\begin{array}{l}\text { R Square } \\
\text { Change }\end{array}$ & F Change & df1 & $\mathrm{df} 2$ & $\begin{array}{c}\text { Sig. F } \\
\text { Change }\end{array}$ & \\
\hline 1 & .905 & .820 & .813 & 40.214 & .820 & 125.556 & 8 & 221 & .000 & 1.858 \\
\hline
\end{tabular}

+ ) Durbin- Watson $=1,858$ coefficient $=1,858$, the research model has no autocorrelation.

+ ) With the coefficient R Square $=0.82$, said that the independent variables in the model explained $82 \%$ about the dependent variable.

The testing results show a model that the author chooses is a relatively good choice when there are no self-correlation defects in the model and independent variables which explain more than $90 \%$ of dependent variables (The result meets requirements when R Square $>=0,7$ )

Table 4

Results of analysis of variance

\begin{tabular}{|c|c|c|c|c|c|c|}
\hline \multicolumn{2}{|c|}{ Model } & Sum of Squares & Df & Mean Square & $\mathrm{F}$ & Sig. \\
\hline 1 & Regression & 1624322.183 & 8 & 203040.273 & 125.556 & .000 \\
\hline & Residual & 357385.364 & 221 & 1617.128 & & \\
\hline & Total & 1981707.548 & 229 & & & \\
\hline
\end{tabular}

Source: Processing results from the survey data 
The results from table 4 above show:

With a coefficient of Sig $=0,000$; test $\mathrm{F}=125,556$, so the research model is suitable.

From data collected through the household interview process, combined with the help of SPSS 20.0 software. The study uses the least square method to examine the impact of industrial parks development on people's livelihoods:

Table 5

$\underline{\text { Regression coefficients }}$

\begin{tabular}{|c|c|c|c|c|c|c|}
\hline & \multirow[t]{2}{*}{ Model } & \multicolumn{2}{|c|}{$\begin{array}{l}\text { Unstandardized Coeffi- } \\
\text { cients }\end{array}$} & \multirow{2}{*}{$\begin{array}{c}\text { Standardized Coeffi- } \\
\text { cients }\end{array}$} & \multirow[t]{2}{*}{$\mathrm{T}$} & \multirow[t]{2}{*}{ Sig. } \\
\hline & & B & Std. Error & & & \\
\hline \multirow[t]{9}{*}{1} & (Constant) & 35.691 & 11.995 & & 2.975 & .003 \\
\hline & So_luong_lao_dong_ho & 8.106 & 2.490 & .103 & 3.256 & .001 \\
\hline & $\mathrm{S}$ dat bi mat & .029 & .003 & .327 & 8.862 & .000 \\
\hline & Tiep_can_CS & 16.473 & 6.083 & .081 & 2.708 & .007 \\
\hline & DT_Phi_NN & .356 & .035 & .350 & 10.116 & .000 \\
\hline & SL_Viec_lam_KCN & 17.279 & 3.311 & .185 & 5.219 & .000 \\
\hline & $\mathrm{SL}_{-}^{-} \mathrm{LD}_{-} \overline{\mathrm{K}} \mathrm{CN}$ & 11.326 & 3.364 & .131 & 3.367 & .001 \\
\hline & SL_that_nghiep_KCN & -22.370 & 3.456 & -.222 & -6.473 & .000 \\
\hline & Giao thong & 5.177 & 3.001 & .051 & 1.725 & .086 \\
\hline
\end{tabular}

Source: Processing results from the survey data

According to Table 5, all variables in the study are statistically significant with a threshold of 0.1 . The land area lost due to industrial park construction (S_dat_bi_mat), the coefficient of the land area lost due to industrial park construction is 0.029 , which means, when people lose land to build industrial parks, their income increased. The people who have money for compensation from losing land due to the construction of industrial parks have changed to a new lifestyle from farming to trading goods, providing services or building motels for workers. Accessibility of preferential policies of households (Tiep_can_CS): incentives from the authorities that people can access are an effective channel to help improve people's income. Actual research results show people's income will improve when people have an approach to the policy. Research results of the author are identical with previous studies. Non-agricultural investment (DT_Phi_NN): the author's research results support the opinion of Phuong et al. (2013) the coefficient of non-agricultural investment variable has a positive sign and has a value of 0.356. When investing in non-agricultural of one thousand and more, people's income increased by 0.356 dong. Transportation system after the industrial park (Giao_thong): the research findings show that the more convenient the transport system, the higher people's income. With the coefficient of the traffic system variable after the industrial park is 5.177, the research results of the author are not consistent with the views of Paul and Sarma (2013), in the opinion of the author, when the industrial park was built, transportation system could be upgraded to meet the transportation needs of enterprises operating in industrial parks, this is absolutely favorable for households doing business and trading around industrial parks. Therefore, the more convenient the transportation system, the more people's income. According to the results of the discussion group of people living around the industrial park shows:

Group 1: The industrial parks are built and developed have a relatively large influence on people's lives, with both good and bad influences, transportation system after industrial parks: better transportation system, more convenient for people living around industrial parks. It is completely possible to compare the transportation system around industrial parks before and after having industrial parks. After the industrial park has been developed, the transport system changes to a more modern, more convenient and easier-to-move appearance.

Group 2: The new construction and repair of the road system to meet the requirements of enterprises, since then, it has created a competitive advantage for the locality in attracting investment capital, opening up job opportunities for local people in the industrial park. Besides, the convenient transportation system also indirectly opens up business opportunities, create a new livelihood strategy for local people in industrial areas, along with the advantages for people living around the industrial park on the move.

Fig. 3. Summary of people's opinions about the infrastructure system when developing the industrial park 
Number of jobs increased when the industrial park was built (SL_Viec_lam_KCN): the number of extra jobs created when constructing industrial parks contributes to increasing the income for people living around the industrial parks. The coefficient of this research variable is 17.279 and the author's research results also support previous studies of Phong (2007), Tuyen (2013) and Tuyen and Van Huong (2014). Number of workers in industrial parks (SL_LD_KCN): the research findings return the coefficient of the number of workers in industrial parks is 11.326, showing the positive relationship between the research variable and income. Income increases as more jobs in the industrial park are created. Number of unemployed laborers when the industrial park was built (SL_that_nghiep_KCN): It is undeniable that, when constructing industrial parks, among the households whose land is acquired, there are households who will be unemployed because they have not caught up with the opportunities created by the construction of industrial parks. As a result, the number of unemployed workers remains, household income decreases and at the same time, the relationship between unemployed workers in industrial parks construction and household income is in the opposite relationship. The author's research results also support previous studies of Van Suu (2009) and Phong (2007).

Research findings show that there is a relative difference in the average income per capita of households between industrial parks and non-industrial parks. Using data from a survey of 120 households, including 60 households in the locality with industrial parks and 60 local households without industrial parks, the author used the T-test to test the income difference between these two groups, with the following specific results:

Table 6

Average value of income

\begin{tabular}{rrrrrr}
\hline & KCN_Y_N & N & Mean & Std. Deviation & Std. Error Mean \\
\hline Y & 1 & 60 & 106.767 & 38.3222 & 4.9474 \\
& 0 & 60 & 58.650 & 17.6422 & 2.2776 \\
\hline
\end{tabular}

Source: Processing results from survey data with the help of SPSS20.0 software

The average income of the group with the industrial park seems to be higher than the group without the industrial park, with 60 observations for each group, the average income of the group with the industrial park is about 106.767 million VND / year the group without the industrial park the average value paid about VND 58.65 million / year.

\section{Table 7}

Testing differences in income of household groups in areas with industrial parks and household groups in areas without industrial parks

\begin{tabular}{|c|c|c|c|c|c|c|c|c|c|c|}
\hline & & \multicolumn{2}{|c|}{$\begin{array}{c}\text { Levene's Test for Equal- } \\
\text { ity of Variances }\end{array}$} & \multicolumn{7}{|c|}{ t-test for Equality of Means } \\
\hline & & \multirow[t]{2}{*}{$\mathrm{F}$} & \multirow[t]{2}{*}{ Sig. } & \multirow[t]{2}{*}{$\mathrm{T}$} & \multirow[t]{2}{*}{ Df } & \multirow{2}{*}{$\begin{array}{l}\text { Sig. }(2- \\
\text { tailed) }\end{array}$} & \multirow[t]{2}{*}{ Mean Difference } & \multirow{2}{*}{$\begin{array}{l}\text { Std. Error Dif- } \\
\text { ference }\end{array}$} & \multicolumn{2}{|c|}{$\begin{array}{l}95 \% \text { Confidence Interval of } \\
\text { the Difference }\end{array}$} \\
\hline & & & & & & & & & Lower & Upper \\
\hline \multirow[t]{2}{*}{$\mathrm{Y}$} & $\begin{array}{l}\text { Equal variances } \\
\text { assumed }\end{array}$ & 19.473 & .000 & 8.834 & 118 & .000 & 48.1167 & 5.4465 & 37.3312 & 58.9021 \\
\hline & $\begin{array}{l}\text { Equal variances } \\
\text { not assumed }\end{array}$ & & & 8.834 & 82.934 & .000 & 48.1167 & 5.4465 & 37.2837 & 58.9496 \\
\hline
\end{tabular}

Source: Processing results from survey data with the help of SPSS20.0 software

Levene's Test has Sig. $=0.000<0.05$, which means that there is a difference between the two groups of households with industrial parks and the group of households without industrial parks. We will use the T-test result in Equal variances not assumed. Sir Sig. $=0,000<0.05$ which indicates that there is a difference in average income between two groups of households living in an industrial park and households in areas without industrial parks. Mean Difference value shows that the average annual income value of the group of households with industrial parks is higher than the other group of 48.1167 million VND / year.

\section{Some recommendations}

Based on the research results, industrial park development had both positive and negative effects on people's livelihoods. To advance the positive affect and restrict the negative effects, the research proposed some recommendations as follows:

Creating stable jobs for people with land acquisition in particular and people living around the industrial park in general. The objective of this recommendation is to create jobs for people with land acquisition in particular and people living around industrial parks in general when people have stable jobs, their income and living standards will be stable. To implement this solution should: improve the quality of human resources and labor discipline of people whose land is acquired in particular and of people living around the industrial park in general. 
Promoting vocational training for workers in the areas where industrial parks are invested and developed, which helps people live around the industrial park to meet job requirements in a new context, enhancing job seek ability for people when industrial parks are invested in construction.

Strengthening the responsibility of companies, organizations and units receiving land for households whose land is recovered and households live around industrial parks.

\section{Acknowledgement}

The authors would like to thank the anonymous referees for constructive comments on earlier version of this paper.

\section{References}

Adger, W.N., Kelly, P.M., Ninh, N.H. (2001). Environment, Society and Preciptous Change. In Living with Environmenal Change. Social Vulnerability, adaptation and Resilience in Vietnam. London/New York: Routledge Research Global Environmental Change.

Adger, W. N., Brooks, N., Bentham, G., Agnew, M., \& Eriksen, S. (2005). New indicators of vulnerability and adaptive capacity. Norwich: Tyndall Centre for Climate Change Research.

Benayas, J. R., Martins, A., Nicolau, J. M., \& Schulz, J. J. (2007). Abandonment of agricultural land: an overview of drivers and consequences. CAB reviews: Perspectives in agriculture, veterinary science, nutrition and natural resources, 2(57), $1-14$.

Blomström, M., \& Kokko, A. (1998). Multinational corporations and spillovers. Journal of Economic surveys, $12(3), 247-$ 277.

Blomström, M., \& Sjöholm, F. (1999). Technology transfer and spillovers: Does local participation with multinationals matter?. European economic review, 43(4-6), 915-923.

Bryceson, D. F. (1996). Deagrarianization and rural employment in sub-Saharan Africa: A sectoral perspective. World Development, 24(1), 97-111.

Damborský, M., Wokoun, R., \& Krejčová, N. (2013). The effectiveness of industrial zones support in the Czech Republic, Journal of Ekonomika and Management, 16(4), 104-117.

DFID. (1999). Sustainable livelihood guidance sheets, Hall- International, Inc

GSO. (2006). Questionnaire on Household Living Standard Survey 2006 (VHLSS-2006).

Hanoi, Vietnam: General Statistical Office.

Jansen, H. G., Pender, J., Damon, A., Wielemaker, W., \& Schipper, R. (2006). Policies for sustainable development in the hillside areas of Honduras: A quantitative livelihoods approach. Agricultural Economics, 34(2), 141-153.

Lê Du Phong. (2007). Thu nhập, đời sống, việc làm của người dân có đất bị thu hồi để xây dụng các khu công nghiệp, khu đô thị kết cấu ha tầng kinh tế-xã hội các công trình phục vu lợi ích quốc gia, NXB Chính trị quốc gia, Hà Nội [Le Du Phong, (2007) Income, life, work of people whose land is acquired to build industrial parks, urban areas of socio-economic infrastructure, projects serving national interests, National Political Publishing House, Hanoi].

Melnyk, L. H., Kubatko, O. V., \& Pysarenko, S. (2014). The impact of foreign direct investment on economic growth: Case of post communism transition economies. Problems and perspectives in management, 12(1), 17-24.

Nelson, R., Kokic, P., Crimp, S., Martin, P., Meinke, H., Howden, S. M., ... \& Nidumolu, U. (2010). The vulnerability of Australian rural communities to climate variability and change: Part II-Integrating impacts with adaptive capacity. Environmental Science \& Policy, 13(1), 18-27.

Nelson, R., Kokic, P., Elliston, L., \& King, J. A. (2005). Structural adjustment: a vulnerability index for Australian broadacre agriculture. Australian Commodities: Forecasts and Issues, 12(1), 171.

Nguyen, V., McGrath, T., \& Pamela, W. (2006). Agricultural land distribution in Vietnam: Emerging issues and policy implications. MPRA Paper No. 25587, University Library of Munich, Germany.

Van Suu, N. (2009). Industrialization and Urbanization in Vietnam: How Appropriation of Agricultural Land Use Rights Transformed Farmers' Livelihoods in a Peri-Urban Hanoi Village?. Final Report of an EADN Individual Research Grant Project, EADN Working Paper, 38.

Popescu, R. F., \& Avramescu, T. C. (2008). Eco-Industrial Parks-An Opportunity for the Developing Countries to Achieve Sustainable Development. Zagreb International Review of Economics \& Business, (1), 21-30.

Paul, S., \& Sarma, V. J. (2013). The livelihood effects of industrialization on displaced households: Evidence from Falta Special Economic Zone, West Bengal. ZEW-Centre for European Economic Research Discussion Paper, (13-083).

Siegel, P. (2005). Using an asset-based approach to identify drivers of sustainable rural growth and poverty reduction in Central America: a conceptual framework. The World Bank.

Tuyen, T. Q. (2013). Livelihood strategies for coping land loss among households in VietNam's sub-urban areas. Asian social science, 9(15), 33-46.

Tuyen, T. Q., \& Van Huong, V. (2014), the impact of land loss on household income: The case of HaNoi's sub-urban areas, Viet Nam, International Journal of Business and Society, 15(2), 339 - 358.

Thuận, N. M., Thành, D. N., \& Nghiệp, N. T. (2018). Yếu tố ảnh hưởng đến thu nhập của hộ dân sau thu hồi đất xây dựng khu công nghiệp tỉnh Vĩnh Long. Tạp chí Khoa học Trường Đại học Cần Thơ, 80-90. 


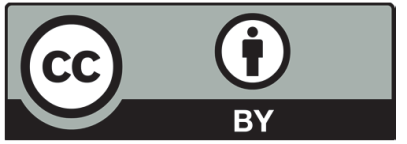

(C) 2020 by the authors; licensee Growing Science, Canada. This is an open access article distributed under the terms and conditions of the Creative Commons Attribution (CC-BY) license (http://creativecommons.org/licenses/by/4.0/). 